\title{
The Effect of Pythium ultimum and Soil Flooding on Two Soybean Cultivars
}

\author{
M. T. Kirkpatrick, C. S. Rothrock, and J. C. Rupe, Department of Plant Pathology, and E. E. Gbur, Agriculture \\ Statistics Lab, University of Arkansas, Fayetteville 72701
}

\begin{abstract}
Kirkpatrick, M. T., Rothrock, C. S., Rupe, J. C., and Gbur, E. E. 2006. The effect of Pythium ultimum and soil flooding on two soybean cultivars. Plant Dis. 90:597-602.

The effect of flooding and Pythium ultimum on soybean, Glycine max, was determined in a series of greenhouse experiments using the cultivars Hutcheson and Archer. Seeds were planted into pasteurized soil either not infested or infested with sand-cornmeal inoculum of P. ultimum and either flooded at emergence for 2 days or at the four leaf node stage (V4) for 5 days. A nonflooded control was included in each experiment. Seeds placed directly into infested soil resulted in little or no stand for Hutcheson regardless of flood treatment, whereas stand was reduced for Archer only in the flooded infested soil treatment. Additional experiments were conducted by placing seed onto a 2- to 5-mm layer of pathogen-free soil on top of the infested soil. Flooding at emergence reduced plant height, growth stage, and top dry weight for Hutcheson and root fresh weight for both cultivars. Greater reductions for Hutcheson in root weight, and top dry weight in $P$. ultimum-infested soil in the soil layer experiments, also indicated that Hutcheson was more susceptible than Archer. Flooding alone decreased root weights, and infestation with P. ultimum reduced weights further resulting in an additive effect. This also was the case for plant height, growth stage, and top dry weight for Hutcheson for flooding at emergence. Root discoloration was greatly increased for both cultivars in infested soil flooded at emergence. Similar results were found when plants were flooded at V4; however, the effect was not as great as with flooding at emergence. These studies indicate that Pythium damping-off and root rot may account for a portion of the negative response of soybean to flooding. The results also indicate that Archer has some resistance to $P$. ultimum.
\end{abstract}

Additional keywords: soil anoxia, soil water

Flood damage to soybeans (Glycine max (L.) Merrill) can be a serious problem in Arkansas because most soybean fields are located on alluvial soils with poor surface and internal drainage. Heavy rainfall or irrigation followed by rainfall can result in prolonged flooded field conditions on these soils. Soybeans have been reported to be sensitive to flooding $(13,15,17)$, resulting in significant reductions in yield compared with nonflooded soybeans $(6,16)$. Flooding of soybeans in the midwestern United States also has resulted in extensive crop damage (20). A desirable solution to this problem is to develop flood tolerant soybean cultivars that yield well following flooding compared with current cultivars (19). At this point, it is unclear if flood damage to soybeans results solely from stress imposed by the physical environ-

Corresponding author: C. S. Rothrock

E-mail: Rothrock@uark.edu

Published with the approval of the director of the Arkansas Agricultural Experiment Station, Fayetteville.

Current address of M. T. Kirkpatrick: Department of Plant and Soil Sciences, Mississippi State University, Mississippi State 39762.

Accepted for publication 14 December 2005.

DOI: 10.1094/PD-90-0597

(C) 2006 The American Phytopathological Society ment, from diseases caused by soilborne plant pathogens favored by this environment, or from a combination of the two.

In a field study conducted in eastern Arkansas, Pythium spp. were the major group of soilborne plant pathogens recovered from flooded soybean roots, and their isolation frequency increased in flooded compared with nonflooded soils (10). Pythium spp. can cause increased disease severity on a variety of plant species under flooded soil conditions (1-3,9,14,21). Preand postemergence damping-off caused by Pythium spp. are frequently associated with high soil water potentials $(3,9,12)$. In addition to damping-off, reductions in root and top weights due to Pythium root rot have been reported to increase with soil saturation (1-3). However, there is limited information available on the effects of Pythium spp. on soybean following temporary soil flooding.

The objectives of this study were to (i) determine the importance of $P$. ultimum, one of the pathogenic species identified on soybeans from the field study (10), on soybeans subjected to soil flooding, and (ii) examine the relationship between disease caused by this pathogen and reported flood tolerance in soybean.

\section{MATERIALS AND METHODS}

Inoculum. $P$. ultimum, isolate 117 , originally isolated from soybean at the
Pine Tree Station near Colt, AR, was transferred to petri plates containing cornmeal agar (CMA) (Difco Laboratories, Detroit, $\mathrm{MI})$ and incubated at room temperature for 3 days. Six $1-\mathrm{cm}^{2}$ plugs of cultures were transferred to 500-ml flasks containing previously sterilized sand-cornmeal medium $(200 \mathrm{ml}$ of sand, $11.2 \mathrm{ml}$ of finely ground cornmeal, and $80 \mathrm{ml}$ of deionized water). The medium was autoclaved for 40 min and then reautoclaved for $40 \mathrm{~min} 24 \mathrm{~h}$ later. The isolate was allowed to colonize the sand-cornmeal medium for 9 days. The flasks were shaken every other day to ensure uniform growth throughout the sand-cornmeal medium. Inoculum consisted of hyphal fragments, based on observations of dilutions of inocula mixed with soil and plated onto CMA.

Greenhouse studies. In order to determine the effects of cultivar, flooding, and soil infestation on P. ultimum, greenhouse experiments were conducted using a Calloway silt loam (Glossaquic fragiudalf) soil collected from a field with a history of soybean and rice production that had been cropped the previous year to rice at the Pine Tree Station. The soil was steam pasteurized at $60^{\circ} \mathrm{C}$ for $30 \mathrm{~min}$ prior to use Soil $(4,500 \mathrm{~g}$ oven dry weight equivalent [odw]) was placed into each pot consisting of a PVC pipe $(15 \mathrm{~cm}$ diameter by $35 \mathrm{~cm}$ long) with fiberglass screen on the bottom.

Four sets of greenhouse experiments were conducted. There were two sets of experiments with flood time at emergence and another two sets with flood time at the fourth leaf node stage, V4 (4). An emergence and V4 experiment were conducted at the same time. Since inoculum placement had a dramatic effect on emergence of the cultivar Hutcheson, experiments differing in inoculum placement were conducted, with two sets of no soil layer experiments and two sets of experiments with a layer of pasteurized soil separating the seed from the inoculum. With the soil layer experiments, plant growth could be compared between the two cultivars. Each of these experiments (flooding at emergence with no soil layer, flooding at V4 with no soil layer, flooding at emergence with a soil layer, and flooding at V4 with a soil layer) was repeated, making eight separate experiments. No data are presented for the no soil layer experiments flooded at V4 because of the lack of stand establishment for Hutcheson.

The experimental design for each set of experiments was a split-split plot with cultivar being the main plot, flooding as 
the split plot, and infestation as the splitsplit plot. In each experiment, treatments were replicated three times. The two cultivars used in each experiment were Hutcheson, a widely planted cultivar in Arkansas, and Archer, which showed flood tolerance in a previous field study (10). Ten seeds of each cultivar were planted in the pots and were thinned to five or three plants after the flood treatment at emergence or the V4 growth stage, respectively. Emergence was defined as more than $70 \%$ of the seed planted reaching the crookneck stage in the noninfested pots. Flood treatments were applied for 2 days at emergence or 5 days at the V4 growth stage by placing the pots in 21.1-liter buckets and maintaining a flood level $2 \mathrm{~cm}$ above the soil surface. Flooding was extended beyond 2 days for the V4 growth stage experiments, as a flood response was found for soybean growth only after irrigation for 4 days or longer in field studies (16). Soil for half of the pots in each experiment was artificially infested with sand-cornmeal inoculum. Greenhouse experiments one (94 $\mathrm{g}$ of inoculum/pot) and two (50 $\mathrm{g}$ of inoculum/pot), designated $\mathrm{GH} 1$ and $\mathrm{GH} 2$, respectively, were conducted by placing the seeds directly into the infested soil. For experiments three and four (GH3 and GH4), seeds were placed onto a layer of pathogen-free pasteurized soil ( 2 to $5 \mathrm{~mm}$ in depth) on top of the infested soil ( $50 \mathrm{~g}$ of inoculum/pot). Inoculum densities were determined for each greenhouse experiment by bulking soil samples from each infested pot. Twentyfive grams of soil (wet weight) was added to dilute water agar $(0.2 \%)$ to give a volume of $250 \mathrm{ml}$ and shaken on a wristaction shaker for $20 \mathrm{~min}$. Inoculum density was determined by a dilution spread-plate technique on the selective medium $\mathrm{P}_{5} \mathrm{ARP}$ (7). Populations for GH1, GH2, GH3, and GH4 were 234, 159, 374, and 204 CFU/g of soil (odw), respectively. Pythium populations of $200 \mathrm{CFU} / \mathrm{g}$ of soil (odw) were determined for the field soil used in the study prior to pasteurization by the same technique.

Data collection. Flooding was done at 4 days after planting for the emergence experiments. Stand counts were recorded at 7

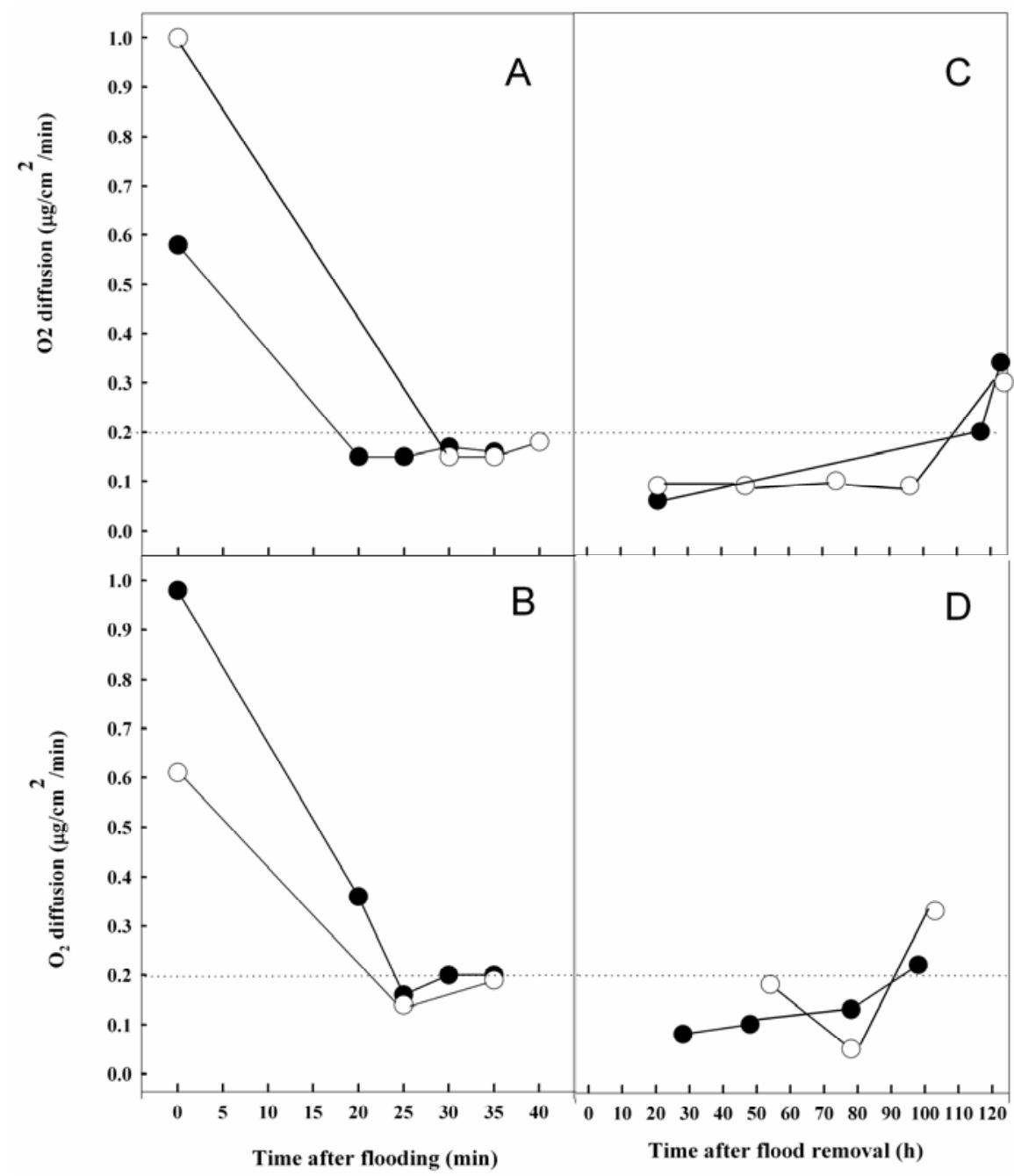

Fig. 1. Soil oxygen diffusion rates for experiments GH1 (•) and GH2 (O) for flooding at emergence (A) or V4 stage (B), and after the flood treatment was removed at emergence (C) or V4 (D). Oxygen diffusion rate limiting to root growth occurs at approximately $0.2 \mu \mathrm{g} / \mathrm{cm}^{2} / \mathrm{min}$. days after planting, after removal of the flood. The plants were allowed to grow for 12 days after the flood-at-emergence was removed and for 11 days after the flood at the V4 growth stage was removed before terminating an experiment. Plant height and growth stage were recorded for all of the plants in each pot and averaged. Plant tops were cut from the root system, and an average weight per pot was recorded for top and root fresh weights. The tops were placed into a drying oven for $48 \mathrm{~h}$ at $65^{\circ} \mathrm{C}$ and weighed again to obtain top dry weight. The roots were rinsed and visually rated for discoloration on a scale from 0 to 5 with $0=$ no discoloration, $1=1$ to $10 \%$, $2=11$ to $25 \%, 3=26$ to $50 \%, 4=51$ to $75 \%$, and $5=76$ to $100 \%$ discoloration of the root system. Before analysis, individual root ratings were converted to the midpoint percentages of the range for the rating. The roots were then rinsed in running tap water for $20 \mathrm{~min}$ and surfacedisinfested in a $0.5 \% \mathrm{NaClO}$ solution for $90 \mathrm{~s}$. The roots were blotted dry and incubated on $\mathrm{P}_{5} \mathrm{ARP}$ at room temperature for $48 \mathrm{~h}$, and the presence of Pythium was recorded.

Soil and air temperatures were monitored with a Hobo Pro Series temperature data recorder (Onset Computers, Pocasset, MA). Soil oxygen levels were monitored with a soil oxygen diffusion ratemeter Model D (Jensen Instruments, Tacoma, WA). Soil oxygen was monitored from the onset of the flood treatment until soil oxygen became limiting to root growth $(<0.2$ $\mu \mathrm{g} / \mathrm{cm}^{2} / \mathrm{min}$ ), and again after termination of the flood until the oxygen levels were no longer limiting to root growth. Oxygen diffusion rates were monitored by placing four platinum electrodes to a depth of $7 \mathrm{~cm}$ in each of two nonflooded and four flooded pots.

Statistics. Analyses of variance were done using SAS Version 8 (SAS Institute, Cary, NC). Each of the four sets of experiments was analyzed separately. Repetitions of the experiments were combined, as analyses of the residuals did not indicate unequal variances across experiments. Plant stands were analyzed over the nolayer experiments (GH1 and $\mathrm{GH} 2$ ) for flooding at emergence. Analysis of variance for flooding at emergence or V4 was conducted over experiments for all parameters for the soil-layer experiments (GH3 and GH4). Since Pythium spp. were not recovered from the noninfested treatments, these treatments were excluded from analyses for Pythium recovery. Least significant differences were calculated for the main effects and interaction means using the guidelines provided by Little and Hills (11).

\section{RESULTS}

The mean air temperature during the experiments was $25.4^{\circ} \mathrm{C}$ (range 23.8 to $29.4^{\circ} \mathrm{C}$ ). Soil temperatures were very simi- 
lar to air temperatures for both flood treatments. The mean soil oxygen diffusion rate for the no-flood treatments was $0.6 \mu \mathrm{g} / \mathrm{cm}^{2} / \mathrm{min}$ (range 0.4 to 1.0 $\mu \mathrm{g} / \mathrm{cm}^{2} / \mathrm{min}$ ). For the flood treatments at emergence and the V4 growth stage, soil oxygen diffusion rates became limiting approximately 20 to $30 \mathrm{~min}$ after the flood treatment was applied (Fig. 1). Once the flood was removed, it took approximately $115 \mathrm{~h}$ for soil oxygen diffusion rates to no longer be limiting to the plant following the flood at emergence. Following the flood at the V4 growth stage, it took approximately $90 \mathrm{~h}$ for oxygen to no longer be limiting.

Flooding at emergence no soil layer experiments. Plant stand at 7 days after planting for flooding at emergence had a significant cultivar by flooding by inoculum interaction for the no-layer experiments (GH1 and GH2) (Table 1); thus, interaction means are presented for the treatments (Table 2). Hutcheson had little or no stand (no flood, 1.50 plants; flood, 0 plants) in the no-layer experiments when seed were planted directly into infested soil (Table 2). Flooding did not reduce the stand of Hutcheson in noninfested soil. Archer had significantly greater stand counts for the infested soil treatments in the no-layer experiments for both flood treatments compared with Hutcheson (Table 2). However, Archer had a significant reduction in plant stand for the infested soil treatment following flooding compared with the infested no-

Table 1. Analysis of variance $P$ values for the no-layer and soil-layer experiments, two runs for each experiment (Exp), for the effect of the soybean cultivars Archer and Hutcheson (Cult), flooding at emergence (Flood), and infestation with Pythium ultimum (Infested) on plant stand ${ }^{\mathrm{a}}$

\begin{tabular}{lcc}
\hline & \multicolumn{2}{c}{$P$ values $^{\mathbf{b}}$} \\
\cline { 2 - 3 } Source & $\begin{array}{c}\text { No } \\
\text { layer }\end{array}$ & $\begin{array}{c}\text { Soil } \\
\text { layer }\end{array}$ \\
\hline Exp & 0.6779 & 0.0121 \\
Cult & 0.0001 & 0.1648 \\
Exp $\times$ cult & 0.0220 & 0.8203 \\
Flood & 0.0001 & 0.7761 \\
Exp $\times$ flood & 0.0432 & 0.9243 \\
Cult $\times$ flood & 0.0006 & 0.7761 \\
Exp $\times$ cult $\times$ flood & 0.5311 & 0.5119 \\
Infested & 0.0001 & 0.0030 \\
Exp $\times$ infested & 0.8732 & 0.1872 \\
Cult $\times$ infested & 0.0001 & 0.0611 \\
Exp $\times$ cult $\times$ infested & 0.4292 & 0.9169 \\
Flood $\times$ infested & 0.0001 & 0.7546 \\
Exp $\times$ flood $\times$ infested & 0.0511 & 0.2607 \\
Cult $\times$ flood $\times$ infested & 0.0071 & 0.1314 \\
Exp $\times$ cult $\times$ flood & 0.8732 & 0.3543 \\
$\quad \times$ infested & & \\
\hline
\end{tabular}

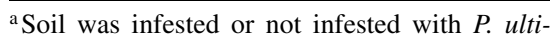
mum, and 10 seeds of Archer or Hutcheson were planted into the soil treatment (no layer: $\mathrm{GH} 1$ and GH2) or onto a layer of pasteurized soil (soil layer: $\mathrm{GH} 3$ and $\mathrm{GH} 4$ ).

${ }^{\mathrm{b}} P$ values smaller than 0.05 indicate statistical significance at the 5\% level.

${ }^{c}$ Each source of variation has one degree of freedom. flood treatment or noninfested flood treatment. Slight differences in stand between experiments for cultivar or flood resulted in a significant interaction, but levels of significance were low compared with $P$ values for main effects.

Flooding at emergence soil layer experiments. Infestation significantly reduced plant stand compared with noninfested soil for both Archer and Hutcheson in the soil-layer experiments (GH3 and GH4), 9.46 out of 10 seed planted compared with 8.08 , respectively (Table 1 ). Flooding did not influence plant stand (8.71) compared with the no-flood treatment (8.83). Archer plant stand (9.21) did not differ from plant stand for Hutcheson (8.33). Plant stand for experiment $\mathrm{GH} 3$ (8.38) was significantly less than experiment GH4 (9.17). Planting seed on pasteurized soil in the soil-layer experiments allowed sufficient stand establishment for comparison of plant growth and development between Archer and Hutcheson for the different treatments, which did not occur in the no layer experiments.

Table 2. Plant stand for two soybean cultivars at 7 days, after termination of flooding at emergence, when seed were planted directly into soil infested with Pythium ultimum or noninfested soil ${ }^{\mathrm{a}}$

\begin{tabular}{lccccc}
\hline & \multicolumn{3}{c}{ Cultivar } \\
\cline { 2 - 3 } \cline { 5 - 6 } Flood & \multicolumn{2}{c}{ Archer } & & \multicolumn{2}{c}{ Hutcheson } \\
\cline { 2 - 3 } \cline { 5 - 6 } & Noninfested & Infested & & Noninfested & Infested \\
\hline- & 9.83 & 8.83 & & 9.17 & 1.50 \\
+ & 8.83 & 3.67 & & 8.67 & 0.00 \\
LSD $^{b}$ & 1.54 & & & & \\
LSD $^{\mathrm{c}}$ & 0.99 & & & & \\
LSD $^{d}$ & 1.19 & & & & \\
\hline
\end{tabular}

${ }^{a}$ Means represent the combined data from experiments GH1 and GH2, with 10 seeds planted per experimental unit.

${ }^{\mathrm{b}}$ LSD (least significant difference) to compare infestation treatments within the same cultivar and flood treatment $(P=0.05)$.

${ }^{c}$ LSD to compare flood treatments within the same cultivar and same or different infestation treatments $(P=0.05)$.

${ }^{\mathrm{d}}$ LSD to compare cultivars within the same or different flood and infestation treatments $(P=0.05)$.

Table 3. Analysis of variance $P$ values ${ }^{\mathrm{a}}$ for the soil-layer experiments (Exp) $)^{\mathrm{b}}$, for the effects of the soybean cultivars Archer and Hutcheson (Cult), flooding at emergence (Flood), and infestation with Pythium ultimum (Infested) on plant growth

\begin{tabular}{|c|c|c|c|c|c|}
\hline Source $^{c}$ & $\begin{array}{l}\text { Plant } \\
\text { height }\end{array}$ & $\begin{array}{c}\text { Growth } \\
\text { stage }\end{array}$ & $\begin{array}{c}\text { Root fresh } \\
\text { weight }\end{array}$ & $\begin{array}{l}\text { Top dry } \\
\text { weight }\end{array}$ & $\begin{array}{c}\text { Root rot } \\
\text { rating }\end{array}$ \\
\hline Exp & $0.0010^{\mathrm{b}}$ & 0.0031 & 0.0185 & 0.0405 & 0.4315 \\
\hline Cult & 0.8881 & 0.0383 & 0.0392 & 0.0897 & 0.4191 \\
\hline Exp $\times$ cult & 0.0721 & 0.1662 & 0.6530 & 0.8722 & 0.2067 \\
\hline Flood & 0.0260 & 0.5543 & 0.0001 & 0.2723 & 0.0001 \\
\hline Exp $\times$ flood & 0.5899 & 1.0000 & 0.2269 & 0.6270 & 0.5834 \\
\hline Cult $\times$ flood & 0.0002 & 0.0150 & 0.0829 & 0.0098 & 0.5531 \\
\hline Exp $\times$ cult $\times$ flood & 0.4033 & 0.5543 & 0.8073 & 0.7449 & 0.0339 \\
\hline Infested & 0.0001 & 0.0001 & 0.0001 & 0.0001 & 0.0001 \\
\hline Exp $\times$ infested & 0.4000 & 0.0001 & 0.0064 & 1.0000 & 0.2877 \\
\hline Cult $\times$ infested & 0.0607 & 0.0001 & 0.0257 & 0.0357 & 0.0002 \\
\hline Exp $\times$ cult $\times$ infested & 0.4000 & 0.0001 & 0.1629 & 0.5404 & 0.1486 \\
\hline Flood $\times$ infested & 0.3811 & 0.0003 & 0.1173 & 0.1638 & 0.0001 \\
\hline Exp $\times$ flood $\times$ infested & 0.5489 & 0.6126 & 0.0035 & 0.5405 & 0.2740 \\
\hline Cult $\times$ flood $\times$ infested & 0.3811 & 0.6126 & 0.4799 & 0.2289 & 0.0010 \\
\hline Exp $\times$ cult $\times$ flood $\times$ infested & 0.0848 & 0.1409 & 0.0427 & 0.1147 & 0.0127 \\
\hline
\end{tabular}

${ }^{a} P$ values smaller than 0.05 indicate statistical significance at the $5 \%$ level.

${ }^{\text {b }}$ Seed planted on a 2- to 5-mm layer of pasteurized soil over the soil treatment, experiments GH3 and GH4.

${ }^{c}$ Each source of variation has one degree of freedom. 
Hutcheson compared with the no flood treatment, but no change was found for Archer (Table 4). For growth stage, an interaction occurred between experiments, cultivar, and infestation (Table 3). Interactions for growth stage were due to a trend for Hutcheson being decreased more dramatically than Archer in experiment GH3 than GH4 from infestation. Growth stage was greater in experiment $\mathrm{GH} 4,2.80$, than in experiment $\mathrm{GH} 3,2.38$. Infested treatments caused significant reductions in growth stage for Archer and Hutcheson (Table 4). Infestation decreased growth stage more for Hutcheson than for Archer relative to their noninfested treatments. Plant development as measured by growth stage was slowed in infested soil for both flood treatments (Table 5). Flooding slowed plant development only for the infested soil treatment. Significant interactions occurred among a number of factors for root weight because inoculum did not have as great an impact on root weight in experiment $\mathrm{GH} 4$ as experiment $\mathrm{GH} 3$, but they showed similar trends. Root weight for experiment $\mathrm{GH} 4$ was $7.38 \mathrm{~g}$ compared with $5.70 \mathrm{~g}$ for experiment GH3. Flooding significantly decreased root weight from $7.85 \mathrm{~g}$ for the no flood treatment to $5.23 \mathrm{~g}$ for the flood treatment (Table 3). Infestation resulted in significantly lower root weights for Archer and Hutcheson (Table 4). Fresh root weight was reduced for Hutcheson compared with Archer for the infested treatment, but not for the noninfested treatment.

Significant interactions occurred for all main effects for root rot rating as a result of a trend for flooding not having as great an impact on root rot rating for infested soil for Archer in GH3 as GH4, but these were mainly differences in magnitude. Flooding of infested soil resulted in significantly greater root ratings for both cultivars, but only for Archer for the noninfested soil (Table 5). Similarly, infestation increased root rot ratings only for flooded compared with nonflooded soils. Hutcheson had significantly greater root rot ratings than Archer for the flooded infested treatment, but this was not a con- sistent response in both experiments (data not shown).

Flooding at V4 soil layer experiments. For experiments used to examine the effects of flooding at V4, few interactions were significant (Table 6). For flooding at $\mathrm{V} 4$, an interaction among all of the factors resulted from little consistency in treatment response for plant height (data not shown). Flooding at V4 significantly increased plant development (growth stage), while infestation significantly decreased plant development for both cultivars (Table 7). Soybean development was significantly greater on average in experiment $\mathrm{GH} 4$ than in GH3, 6.35 and 6.15, respectively. Root weights were significantly reduced by $P$. ultimum for both cultivars (Table 7). Flooding decreased root weight for both cultivars. For flooding at V4, P. ultimum decreased top dry weights compared with the noninfested treatment. Top dry weight increased with flooding compared to the no flood treatment. The experiment by cultivar interaction for root fresh weight and top dry weight resulted from little difference between cultivars in experiment
GH3, but greater growth for Hutcheson than Archer in experiment GH4. Increased root discoloration was observed for both cultivars for infestation. Flooding increased root rot ratings for both cultivars, and discoloration was greater for Hutcheson than for Archer under flooded conditions (Table 7). The experiment by flood by infestation interaction for root rot rating occurred from greater differences between the infested and noninfested treatments for the flood treatment in $\mathrm{GH} 4$ than in GH3.

$P$. ultimum was not recovered from plants in the noninfested treatments. In the soil-layer experiments, where seeds of Archer and Hutcheson were placed on top of a layer of pathogen-free soil, flooding at emergence resulted in a significant flood effect $(P=0.0356)$ and a nearly significant cultivar effect for Pythium recovery $(P=$ 0.0514). Recovery of Pythium from both cultivars was significantly greater when flooded at emergence $(38.3 \%)$ than when not flooded $(20.0 \%)$. Hutcheson had a greater percent recovery $(38.3 \%)$ than Archer $(20.0 \%)$. Flooding at V4 resulted in

Table 5. The effect of Pythium ultimum and flooding at soybean emergence on growth stage and root discoloration for the soybean cultivars Archer and Hutcheson (Hutch) when seed were planted onto a layer of pasteurized soil over the soil infestation treatment ${ }^{\mathrm{a}}$

\begin{tabular}{|c|c|c|c|c|c|c|}
\hline \multirow[b]{3}{*}{ P. ultimum } & & & \multicolumn{4}{|c|}{ Root rot rating ${ }^{b}$} \\
\hline & \multicolumn{2}{|c|}{ Growth stage $^{c}$} & \multicolumn{2}{|c|}{ Archer } & \multicolumn{2}{|c|}{ Hutch } \\
\hline & No flood & Flood & No flood & Flood & No flood & Flood \\
\hline Noninfested & 2.75 & 2.87 & 6.13 & 16.73 & 5.37 & 6.33 \\
\hline Infested & 2.47 & 2.28 & 9.33 & 32.93 & 11.07 & 49.50 \\
\hline $\mathrm{LSD}^{\mathrm{d}}$ & \multirow{2}{*}{\multicolumn{2}{|c|}{$\begin{array}{l}0.10 \\
0.14\end{array}$}} & & & & \\
\hline $\mathrm{LSD}^{\mathrm{e}}$ & & & & & & \\
\hline $\operatorname{LSD}^{f}$ & & & \multicolumn{4}{|c|}{9.09} \\
\hline LSD $^{g}$ & & & \multicolumn{4}{|c|}{8.21} \\
\hline $\mathrm{LSD}^{\mathrm{h}}$ & & & \multicolumn{4}{|c|}{11.25} \\
\hline
\end{tabular}

a Means represent the combined data for experiments GH3 and GH4.

${ }^{\mathrm{b}}$ Root rating scale from 0 to 5 with $0=$ no discoloration, $1=1$ to $10 \%, 2=11$ to $25 \%, 3=26$ to $50 \%$, $4=51$ to $75 \%$, and $5=76$ to $100 \%$ discoloration and analyzed as midpoint percentages of the rating.

${ }^{c}$ Growth stage in number of leaf nodes.

${ }^{\mathrm{d}}$ LSD (least significant difference) to compare infestation treatments within same flood treatment $(P=$ $0.05)$

${ }^{\mathrm{e}}$ LSD to compare flood treatments within the same or different infestation treatments $(P=0.05)$.

${ }^{\mathrm{f}}$ LSD to compare infestation treatments within the same cultivar and flood treatments $(P=0.05)$.

$\mathrm{g}$ LSD to compare flood treatments within the same cultivar and same or different infestation treatments $(P=0.05)$

${ }^{\mathrm{h}}$ LSD to compare cultivars within the same or different flood and infestation treatments $(P=0.05)$.

Table 4. The effect of Pythium ultimum and flooding at soybean emergence on plant growth for the soybean cultivars Archer and Hutcheson (Hutch) when seeds were planted onto a layer of pasteurized soil over the soil infestation treatment ${ }^{\mathrm{a}}$

\begin{tabular}{|c|c|c|c|c|c|c|c|c|c|c|c|c|}
\hline \multirow[b]{2}{*}{ Cultivar } & \multicolumn{2}{|c|}{ Plant height (cm) } & \multicolumn{2}{|c|}{ Growth stage $^{\mathrm{b}}$} & \multicolumn{2}{|c|}{ Growth stage $^{\text {b }}$} & \multicolumn{2}{|c|}{ Top dry weight (g) } & \multicolumn{2}{|c|}{ Top dry weight (g) } & \multicolumn{2}{|c|}{ Root fresh weight (g) } \\
\hline & No flood & Flood & No flood & Flood & Noninfested & Infested & No flood & Flood & Noninfested & Infested & Noninfested & Infested \\
\hline Archer & 24.72 & 28.55 & 2.45 & 2.58 & 2.65 & 2.38 & 1.44 & 1.55 & 1.66 & 1.33 & 7.64 & 6.24 \\
\hline Hutch & 27.33 & 25.77 & 2.77 & 2.57 & 2.97 & 2.37 & 1.50 & 1.28 & 1.64 & 1.13 & 7.48 & 4.80 \\
\hline $\mathrm{LSD}^{\mathrm{c}}$ & \multicolumn{2}{|c|}{1.36} & \multicolumn{2}{|c|}{0.18} & & & \multicolumn{2}{|c|}{0.16} & & & & \\
\hline $\operatorname{LSD}^{\mathrm{d}}$ & \multirow{3}{*}{\multicolumn{2}{|c|}{1.81}} & \multicolumn{2}{|c|}{0.18} & & & \multicolumn{2}{|c|}{0.18} & & \\
\hline $\mathrm{LSD}^{\mathrm{e}}$ & & & & & 010 & & & & \multirow{2}{*}{\multicolumn{2}{|c|}{$\begin{array}{l}0.12 \\
0.16\end{array}$}} & \multicolumn{2}{|c|}{0.78} \\
\hline $\operatorname{LSD}^{\mathrm{f}}$ & & & & & \multicolumn{2}{|c|}{0.15} & & & & & \multicolumn{2}{|c|}{0.91} \\
\hline
\end{tabular}

\footnotetext{
${ }^{a}$ Means represent the combined data for experiments GH3 and GH4.

$\mathrm{b}$ Growth stage in number of leaf nodes.

${ }^{\mathrm{c}}$ LSD (least significant difference) to compare flood treatments within same cultivar $(P=0.05)$.

d LSD to compare cultivars within same or different flood treatments $(P=0.05)$.

${ }^{\mathrm{e}} \mathrm{LSD}$ to compare infestation treatments within same cultivar $(P=0.05)$.

${ }^{\mathrm{f}} \mathrm{LSD}$ to compare cultivars within same or different infestation treatments $(P=0.05)$.
} 
a significant flood by cultivar interaction $(P=0.0176)$ for Pythium recovery. The recovery of Pythium was greater when flooded at V4 for Archer, $89.0 \%$, compared with no flooding, $22.2 \%$. However, $P y$ thium recovery for Hutcheson was $83.3 \%$ when not flooded and $77.8 \%$ when flooded. Isolation for Archer was lower than for Hutcheson under the no flood treatment. Archer had an isolation frequency of $83.3 \%$ (90.0\% flooded, $76.7 \%$ no flood) for the no-layer experiments.

\section{DISCUSSION}

Flooding at emergence was more detrimental to growth and development of soybean than flooding at V4 in controlled environmental experiments. Flooding at emergence reduced plant height, plant development, and top dry weight for Hutcheson and root fresh weight for both cultivars. For flooding at V4, only root fresh weight was reduced for both cultivars. These results are similar to those of Russell et al. (15), who found that soybean seedlings were sensitive to flooding. In the current study, plant stand was not affected by flooding alone for either cultivar. Flooding at either emergence or V4 resulted in increased root rot ratings. Treatment responses for root weight and root ratings had the largest differences for flooding compared with the other plant parameters measured. Flooding did not consistently reduce plant development or top dry weight. These results differ from field studies by Scott et al. (16). Soil anoxia occurred as a result of flooding in these studies, with oxygen diffusion rates limiting root growth for flooding at emergence and at V4.

P. ultimum significantly affected plant stand. When seeds were placed directly into the infested soil, Hutcheson had little or no stand. Hutcheson appeared to be more susceptible than Archer to P. ultimum, because even when a soil layer was placed between the seeds of Hutcheson and the pathogen, significant stand reductions still occurred. Greater reductions for Hutcheson in root weight and top dry weight in $P$. ultimum-infested soil, especially when flooded at emergence, also indicated that Hutcheson was more susceptible than Archer. When flooded at the V4 growth stage, differences between the two cultivars were less dramatic than with flooding at emergence. These results indicate the importance of $P$. ultimum under flooded soil conditions on soybean, especially at emergence.

While rare, Pythium resistance has been reported for soybeans $(5,8)$. Keeling (8) reported the cultivar Semmes was more resistant than Hood. Differences were attributed to more than twice the quantity of soluble carbohydrates being exuded from seeds of the susceptible cultivar compared with the resistant cultivar. Griffin (5) found that the cultivar Dare had significantly greater emergence in $P y$ thium-infested soil compared with the cultivar Essex. Griffin further demonstrated that the percentage of cotyledons and hypocotyls colonized by $P$. ultimum was significantly greater, while hypocotyl length was significantly lower, for Essex compared with Dare.

An additive effect was observed for flooding and soil infestation with $P$. ultimum. This additive effect was evident for root weight, where flooding caused decreased root weights and the presence of $P$. ultimum decreased root weights further. This also was the case for plant height, growth stage, and top dry weight for Hutcheson for flooding at emergence. $P$. ultimum also was recovered more frequently from soybean roots that had been flooded than from nonflooded soybeans. Both cultivars showed the same trends, but reductions in root weight for Archer were not as great as for Hutcheson. Archer appeared to be more resistant than Hutcheson to root weight reductions when P. ultimum and flooding at emergence occurred together. Increased disease from Pythium spp. under flooded conditions has been reported by other researchers (1-3).

It is still unclear whether resistance to $P$. ultimum, as seen with Archer, is related to reported flood tolerance (18). In this study, temporary flooding caused little damage to either cultivar in the absence of the pathogen. Further studies need to be conducted to characterize the resistance in Archer. Cultivar screens should be expanded to include other soilborne plant pathogens,

Table 6. Analysis of variance $P$ values ${ }^{\mathrm{a}}$ for the soil-layer experiments (Exp) for the effects of the soybean cultivars Archer and Hutcheson (Cult), flooding at the V4 growth stage (Flood), and infestation with Pythium ultimum (Infested) on plant growth ${ }^{\mathrm{b}}$

\begin{tabular}{llcccc}
\hline Source & $\begin{array}{c}\text { Plant } \\
\text { height }\end{array}$ & $\begin{array}{c}\text { Growth } \\
\text { stage }\end{array}$ & $\begin{array}{c}\text { Root fresh } \\
\text { weight }\end{array}$ & $\begin{array}{c}\text { Top dry } \\
\text { weight }\end{array}$ & $\begin{array}{c}\text { Root rot } \\
\text { rating }\end{array}$ \\
\hline Exp & $0.0988^{b}$ & 0.0097 & 0.5212 & 0.4819 & 0.8411 \\
Cult & 0.7093 & 0.0087 & 0.0150 & 0.0337 & 0.5053 \\
Exp $\times$ cult & 0.0976 & 0.0548 & 0.0100 & 0.0175 & 0.5265 \\
Flood & 0.0094 & 0.0074 & 0.0001 & 0.0004 & 0.0001 \\
Exp $\times$ flood & 0.5564 & 0.9237 & 0.0925 & 0.9337 & 0.0923 \\
Cult $\times$ flood & 0.1835 & 0.1133 & 0.0228 & 0.5289 & 0.0166 \\
Exp $\times$ cult $\times$ flood & 0.5988 & 0.0974 & 0.0649 & 0.6014 & 0.5532 \\
Infested & 0.0002 & 0.0002 & 0.0002 & 0.0001 & 0.0001 \\
Exp $\times$ infested & 0.0655 & 0.6889 & 0.4139 & 0.4857 & 0.0067 \\
Cult $\times$ infested & 0.6869 & 0.2038 & 0.4744 & 0.0622 & 0.5366 \\
Exp $\times$ cult $\times$ infested & 0.4840 & 0.3232 & 0.4181 & 0.0800 & 0.3459 \\
Flood $\times$ infested & 0.4196 & 0.2787 & 0.7065 & 0.5715 & 0.5311 \\
Exp $\times$ flood $\times$ infested & 0.9531 & 1.0000 & 0.0966 & 0.9733 & 0.0219 \\
Cult $\times$ flood $\times$ infested & 0.4321 & 0.7637 & 0.9494 & 0.1633 & 0.1396 \\
Exp $\times$ cult $\times$ flood $\times$ infested & 0.0052 & 0.5494 & 0.7343 & 0.0800 & 0.9761 \\
\hline
\end{tabular}

a $P$ values smaller than 0.05 indicate statistical significance at the $5 \%$ level.

${ }^{\mathrm{b}}$ Seed planted on a 2- to 5-mm layer of pasteurized soil over the soil treatment, experiments GH3 and GH4.

${ }^{c}$ Each source of variation has one degree of freedom.

Table 7. The effect of Pythium ultimum and flooding at the V4 growth stage on plant growth and root discoloration for the soybean cultivars Archer and Hutcheson (Hutch) when seed were planting onto a layer of pasteurized soil over the soil treatment ${ }^{\mathrm{a}}$

\begin{tabular}{|c|c|c|c|c|c|c|}
\hline \multirow[b]{2}{*}{ Main effect } & \multirow{2}{*}{$\begin{array}{l}\text { Growth } \\
\text { stage }^{\mathrm{c}}\end{array}$} & \multicolumn{2}{|c|}{ Root fresh wt. (g) } & \multirow{2}{*}{$\begin{array}{c}\text { Top dry } \\
\text { weight (g) }\end{array}$} & \multicolumn{2}{|c|}{ Root rot rating ${ }^{b}$} \\
\hline & & Archer & Hutch & & Archer & Hutch \\
\hline \multicolumn{7}{|l|}{ Infestation } \\
\hline Noninfested & $6.45^{* \mathrm{~d}}$ & \multicolumn{2}{|c|}{$22.70 * \mathrm{e}$} & $5.28^{*}$ & \multicolumn{2}{|c|}{$16.20^{* \mathrm{e}}$} \\
\hline Infested & 6.05 & \multicolumn{2}{|c|}{17.37} & 4.22 & \multicolumn{2}{|c|}{24.61} \\
\hline \multicolumn{7}{|l|}{ Flooding } \\
\hline No flood & $6.10 *$ & 19.61 & 25.26 & $4.32 *$ & 12.79 & 9.43 \\
\hline Flood & 6.40 & 16.66 & 18.62 & 5.17 & 26.89 & 32.58 \\
\hline \multicolumn{7}{|l|}{ Cultivar } \\
\hline Archer & $5.98 *$ & & & $4.51^{*}$ & & \\
\hline Hutch & 6.52 & & & 4.98 & & \\
\hline $\operatorname{LSD}^{\mathrm{f}}$ & & \multicolumn{2}{|c|}{2.14} & & \multicolumn{2}{|c|}{4.94} \\
\hline LSD $^{g}$ & & \multicolumn{2}{|c|}{2.98} & & \multicolumn{2}{|c|}{5.48} \\
\hline
\end{tabular}

${ }^{a}$ Means represent the combined data for experiments GH3 and GH4.

${ }^{\mathrm{b}}$ Root rating scale from 0 to 5 with $0=$ no discoloration, $1=1$ to $10 \%, 2=11$ to $25 \%, 3=26$ to $50 \%$, $4=51$ to $75 \%$, and $5=76$ to $100 \%$ discoloration and analyzed as midpoint percentages of the rating. ${ }^{c}$ Growth stage in number of leaf nodes.

${ }^{\mathrm{d}}$ Pair of means within a column and main effect followed by an * are significantly different $(P=0.05)$.

${ }^{\text {e }}$ Means of combined data for both cultivars as a result of a nonsignificant $P$ value.

${ }^{\mathrm{f}} \mathrm{LSD}$ to compare flood treatments for the same cultivar $(P=0.05)$.

${ }^{\mathrm{g}}$ LSD to compare cultivars at the same or different flood treatments $(P=0.05)$. 
such as other Pythium spp. and Phytophthora sojae, that show increased disease development under flooded soil conditions.

\section{ACKNOWLEDGMENTS}

This research was supported in part by grants from the United Soybean Board.

\section{LITERATURE CITED}

1. Biesbrock, J. A., and Hendrix, F. F. 1970. Influence of continuous and periodic soil water conditions on root necrosis of holly caused by Pythium spp. Can. J. Bot. 48:1641-1645.

2. Biesbrock, J. A., and Hendrix, F. F. 1970. Influence of soil water and temperature on root necrosis of peach caused by Pythium spp. Phytopathology 60:880-882.

3. Brown, G. E., and Kennedy, B. W. 1966. Effect of oxygen on Pythium seed rot of soybean. Phytopathology 56:407-411.

4. Fehr, W. R., Caviness, C. E., Burmood, D. T., and Pennington, J. S. 1971. Stage of development descriptions for soybeans, Glycine max (L.) Merr. Crop Sci. 11:929-931.

5. Griffin, G. J. 1990. Importance of Pythium ultimum in a disease syndrome of cv. Essex soybean. Can. J. Plant Pathol. 12:135-140.

6. Heatherly, L. G., and Pringle, H. C. 1991.
Soybean cultivars response to flood irrigation of clay soil. Agron. J. 83:231-236.

7. Jeffers, S. N., and Martin, S. B. 1986. Comparison of two media selective for Phytophthora and Pythium species. Plant Dis. 70:1038-1043.

8. Keeling, B. L. 1974. Soybean seed rot and the relation of seed exudate to host susceptibility. Phytopathology 64:1445-1447.

9. Kerr, A. 1964. The influence of soil moisture on infection of peas by Pythium ultimum. Aust. J. Biol. Sci. 17:676-685.

10. Kirkpatrick, M. T., Rupe, J. C., and Rothrock, C. S. 2006. Soybean response to flooded soil conditions and the association with soilborne plant pathogenic genera. Plant Dis. 90:592596.

11. Little, T. M., and Hills, F. J. 1972. Statistical Methods in Agricultural Research. University of California, Davis.

12. Mondal, S. N., Kageyama, K., and Hyakumachi, M. 1995. Influence of soil matric potential on the debilitation of oospores of $P y$ thium aphanidermatum. Soil Biol. Biochem. 29:1319-1323.

13. Oosterhuis, D. M., Scott, H. D., Hampton, R E., and Wullschleger, S. D. 1990. Physiological responses of two soybean cultivars to shortterm flooding. Environ. Exp. Bot. 30:85-92.

14. Rao, B., Schmitthenner, A. F., Caldwell, R., and Ellett, C. W. 1978. Prevalence and virulence of Pythium species associated with roo rot of corn in poorly drained soil. Phytopathology $68: 1557-1563$.

15. Russell, D. A., Wong, D. L., and Sachs, M. M. 1990. The anaerobic response of soybean. Plant Physiol. 92:401-407.

16. Scott, H. D., DeAngulo, J., Daniels, M. B., and Wood, L. S. 1989. Flood duration effects on soybean growth and yield. Agron. J. 81:631636.

17. Stanley, C. D., Kaspar, T. C., and Taylor, H. M. 1980. Soybean top and root response to temporary water tables imposed at three different growth stages. Agron. J. 72:341-346.

18. VanToai, T. T. 1998. Producing flood tolerant crops. What does it take? Page 68 in: Agron. Abstr. American Society of Agronomy, Madison, WI.

19. VanToai, T. T., Beuerlein, J. E., Schmitthenner, A. F., and St-Martin, S. K. 1994. Genetic variability for flooding tolerance in soybeans. Crop Sci. 34:1112-1115.

20. Wetterauer, D. G., and Killorn, R. J. 1996. Fallow- and flooded-soil syndromes: Effects on crop production. J. Prod. Agric. 9:39-41.

21. Yanar, Y., Lipps, P. E., and Deep, I. W. 1997. Effect of soil saturation duration and soil water content on root rot of maize caused by $P y$ thium arrhenomanes. Plant Dis. 81:475-480. 